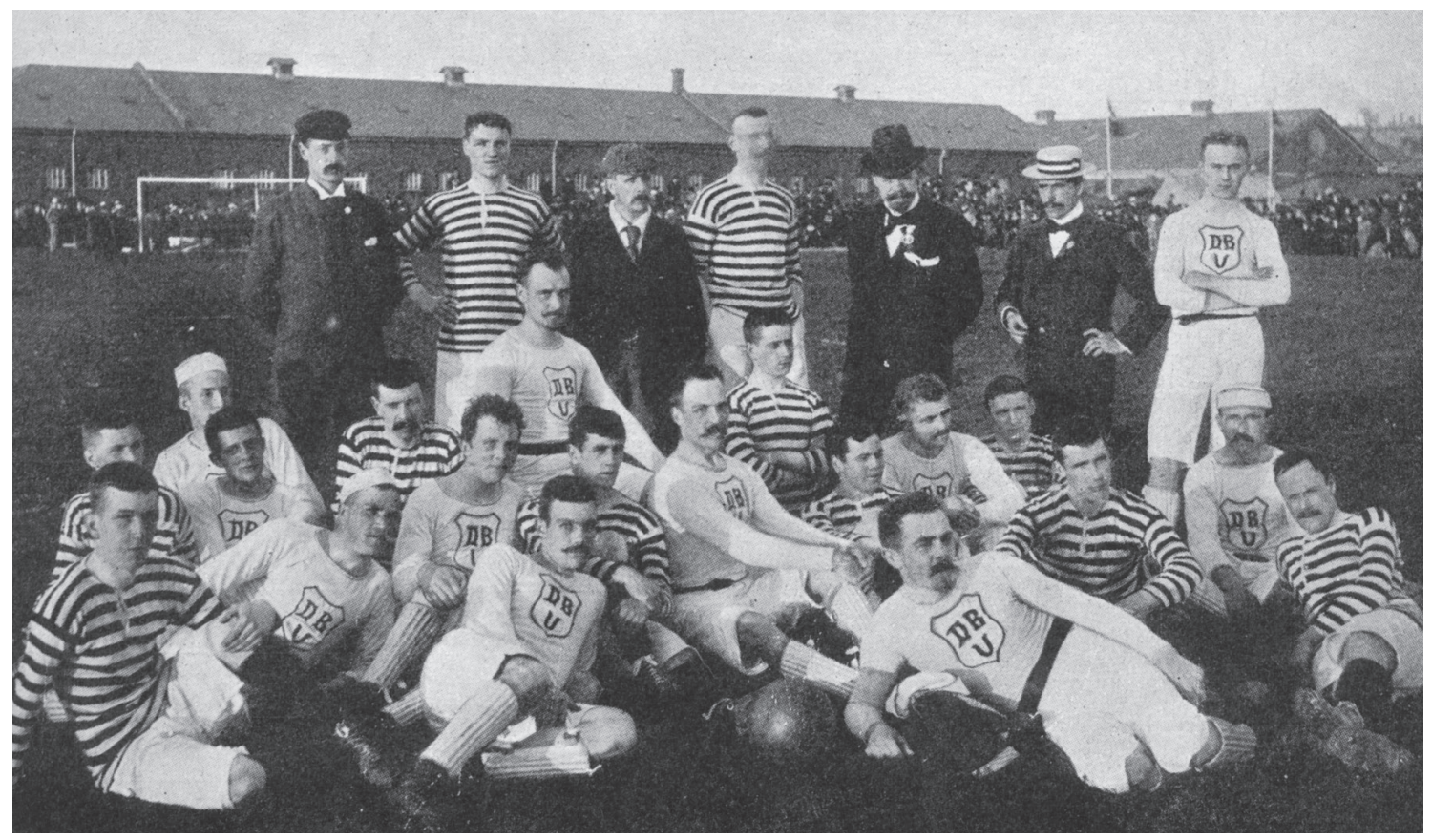

Dansk fodbold tog form i slutningen af 1800-tallet med spredte initiativer fordelt over hele landet. 21 sjællandske og fem jyske klubber oprettede i 1889 Dansk Boldspil Union, og et hovedformål med skabelsen af DBU var at skabe bedre vilkår for fodboldspillet. Med andre ord at gøre opmæerksom på fodboldens sag i forhold til politikere. Her ses et udvalgt DBU-hold mod skotske Queens Park i 1898. (Foto: Johannes Gandil, Dansk fodbold, København, 1939)

\title{
Den svenska idrotts- politikens två sidor Några reflektioner om statens stöd till idrotten och svensk välfärdspolitik
}




\section{INLEDNING}

Våren 2011 inbjöds jag till Kulturdepartementet i Stockholm för att hålla ett föredrag om statens stöd till idrotten. Jag accepterade med glädje. Till saken hör att idrottsfrågor är ett relativt nytt ansvarsområde för Kulturdepartementet. Seminariet skulle därför bli en spännande möjlighet för mig som historiker och idrottsforskare att få diskutera den svenska idrottspolitikens utformning och kännetecken med de tjänstemän som ansvarar för idrottsfrågor i Regeringskansliet. Att skriva själva föredraget visade sig emellertid bli en komplicerad uppgift. Detta beror på att svensk idrottspolitik är ett på flera sätt motsägelsefullt politikområde. Å ena sidan finns det aspekter som uppvisar tydliga beröringspunkter med den generella svenska välfärdspolitiken. A andra sidan finns det även inslag i idrottspolitiken som inte alls följer det gängse mönstret. Idrotten är följaktligen ett politikområde som kan beskrivas på mycket olika sätt: den kan på goda grunder betraktas som själva sinnebilden för svensk välfärdspolitik - men den kan även karakteriseras som en gökunge i det svenska välfärdsboet; som ett udda sidospår i svensk politik, försedd med en egen politisk logik och med ekonomiska förmåner av sällan skådat slag.

Denna artikel är sprungen ur mitt föredrag. Det övergripande syftet är att ge en allmän karaktäristik av statens stöd till idrotten i Sverige. Redogörelsen är uppdelad i två delar. Först visas att idrottspolitiken såväl ideologiskt som i sin konkreta utformning har tydliga likheter med den generella svenska välfärdspolitiken. ${ }^{1}$ Därefter skiftar perspektivet till idrottspolitikens särskiljande drag. Avslutningsvis kommenteras ett antal aktuella förändringsprocesser vilka indikerar att idrotten under senare år börjat förlora sin karaktär som ett udda och avvi- kande politikområde. Denna utveckling har både för och nackdelar för svensk idrott.

\section{OM VÄLFÄRDSPOLITIK OCH SKILDA VÄLFÄRDS- POLITISKA SYSTEM}

Begrepp som välfärdspolitik och välfärdsstat används vanligtvis för att beskriva samhällssystem där staten tagit på sig ett visst mått av ansvar för medborgarnas säkerhet och välfärd i frågor som hälsovård, utbildning och omsorg. Två motiv brukar anföras. Ett första är att skapa trygghet för medborgarna i livets olika skeden. Pensioner kan exempelvis ses som ett sätt att via skatter omfördela resurser från individers yrkesverksamma perioder för att ge dem ett drägligt liv även på äldre dagar. Det andra välfärdspolitiska motivet är solidaritet, det vill säga en strävan att utjämna ekonomiska skillnader mellan olika befolkningsgrupper. ${ }^{2}$

De flesta utvecklade länder kan idag karakteriseras som välfärdsstater i den meningen att de har strategier för att hantera medborgarnas skilda förutsättningar och livsvillkor. Omfattningen och inriktningen på välfärdspolitiken kan emellertid variera. I vissa länder är statens åtagande på det sociala området både omfattande och generellt. I andra politiska system är de offentliga insatserna betydligt mer begränsade och i huvudsak avgränsade till särskilt utsatta samhällsgrupper.

Inom samhällsvetenskapen utgör studiet av olika länders välfärdspolitik ett omfattande forskningsfält. Ett välkänt och inflytelserikt bidrag, och en lämplig utgångspunkt i detta sammanhang, är den danske sociologen Gøsta Esping-Andersens idag klassiska verk The Three Worlds of Welfare Capitalism. ${ }^{3}$ Enligt Esping-Andersen kan alla moderna kapitalistiska länder delas in i tre större kluster av s.k. välfärdsregimer. 
Den första kategorin är liberala välfärdsregimer. I denna välfärdspolitiska modell spelar marknaden en avgörande roll i fördelningen av resurser, sociala tjänster och försäkringsskydd. Statens åtagande är följaktligen begränsat och huvudsakligen inriktat på behovsprövade insatser till de sva-gaste samhällsgrupperna. Som exempel på länder med liberala välfärdssystem kan nämnas USA, Kanada och Australien.

Den andra kategorin utgörs av konservativa välfärdsregimer. I dessa spelar marknadsbaserade välfärdslösningar en begränsad roll. I välfärdspolitiska frågor tillmäts istället familjen stor betydelse - något som ofta sammanhänger med kyrkans stora politiska inflytande på familjepolitikens område. Resultatet blir en välfärdspolitisk modell där bidrag och transfereringar är utformade så att män förväntas förvärvsarbeta medan kvinnor ska ansvara för hem och barn och där staten endast griper in när familjens egna resurser är uttömda. Tyskland och Frankrike brukar betraktas som exempel på denna modell.

Den tredje varianten är socialdemokratiska välfärdsregimer. Kännetecknande för socialdemokratiska välfärdsregimer är att staten axlar ett huvudansvar för befolkningens trygghet och drägliga levnadsstandard. Därtill är de sociala förmånerna inte behovsprövade utan generella och kopplade till medborgarskapet. Utmärkande är även att produktionen av välfärd i huvudsak sker i offentlig regi. Det frikostiga socialpolitiska systemet och den omfattande offentliga sektorn förutsätter dessutom en aktiv arbetsmarknadspolitik med full sysselsättning som mål och relativt höga skatteintäkter.

Mot denna bakgrund kan diskussionen avgränsas till svensk idrottspolitik. Vad kännetecknar egentligen idrotten som statligt politikområde? Och i vilken utsträckning speglas den

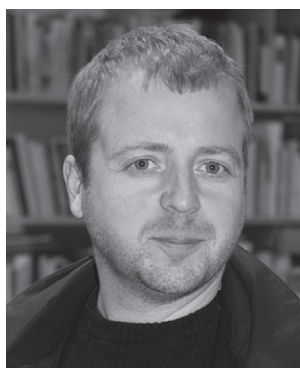

svenska välfärdspolitikens principer i statens stöd till idrotten?

\section{LIKHETER MELLAN STATENS IDROTTSPOLITIK OCH DEN GENERELLA VÄLFÄRDSPOLITIKEN}

Den frivilligt organiserade idrotten utgör ett betydande offentligt åtagande

Som ovan påpekats, kännetecknas svensk välfärdspolitik av en stor offentlig sektor, generösa bidragssystem och långtgående statliga ambitioner i frågor kopplade till människors välfärd. På idrottspolitikens område manifesteras dessa principer genom ett omfattande statligt stöd till den frivilligt organiserade idrottsverksamheten. ${ }^{4}$ Statsbidraget till idrotten instiftades redan 1913. Det är en tydlig markering av statens generellt välvilliga inställning till frivilligt organiserad idrottsutövning. Därtill är det en manifestation av en svensk välfärdspolitik som inte enbart är avgränsad till välfärdens kärnområden (vård, skola, omsorg) utan även inkluderar människors möjlighet till meningsfull fritid. Utgångspunkten är följaktligen att föreningsidrotten - precis som kultur och folkbildning - utgör en fritidsföreteelse som skapar ett samhälleligt mervärde och som därmed är förtjänt av statens hjälpande hand. ${ }^{5}$

De offentliga resurserna till idrotten består både av direkt kontant verksamhetsstöd till förbund och föreningar samt indirekt stöd i form av 
offentligt finansierade och/eller subventionerade idrottsanläggningar. Det statliga (nationella) stödet uppgick år 2010 till 1,8 miljarder SEK (motsvarande cirka 170 miljoner EUR). I bidraget ingår bland annat organisationsstöd till Riksidrottsförbundet (RF) och dess medlemsorganisationer, verksamhetsstöd till Studieförbundet SISU Idrottsutbildarna, medel till idrottsforskning, antidopningsverksamhet och bidrag till förberedelser och deltagande i Olympiska spel och Paralympics. Dessutom tillförs det lokala föreningslivet betydande resurser i form av statligt lokalt aktivitetsstöd och medel till de lokala utvecklingsprojekten "Handslaget " och "Idrottslyftet «. ${ }^{6}$

Det kommunala (lokala) stödet har uppskattats till cirka 4,5 miljarder SEK om året (motsvarande cirka 420 miljoner EUR). ${ }^{7}$ Ungefär en miljard SEK utgörs av kontantbidrag till idrottsföreningar. Resterande medel är indirekta subventioner $\mathrm{i}$ form av föreningslivets fria eller rabatterade utnyttjande av lokaler, utrustning m.m.

\section{VÄLFÄRDSPOLITIKENS UNIVERSELLA OCH EGALITÄRA PRINCIPER: "IDROTT ÅT ALLA"}

Kännetecknande för den svenska välfärdsmodellen är även att politiken utgår från

universella och egalitära principer. Målet är följaktligen att undvika behovsprövade och därmed stigmatiserande bidragsformer till de svagare grupperna i samhället till förmån för system med grundläggande resurser till alla medborgare utifrån en princip om lika omtanke och respekt. ${ }^{8}$ Barnbidrag, utbildning, sjukvård osv. är således generella förmåner som alla medborgare har rätt till oavsett ekonomiska eller andra förutsättningar.

På idrottens område sammanfattas dessa egalitära principer i den klassiska idrottspolitiska devisen "Idrott åt alla«. Formuleringen har använts flitigt i svensk idrott sedan 1960-talet för att markera att idrottsrörelsen är en bred rörelse som välkomnar alla oavsett förutsättningar och ambitionsnivåer. Principen finns dessutom konkretiserad i Riksidrottsförbundets stadgar i uttalanden som att idrottsrörelsen eftersträvar glädje, demokrati och delaktighet samt att verksamheten är öppen för «alla som vill, oavsett nationalitet, etniskt ursprung, religion, ålder, kön eller sexuell läggning samt fysiska och psykiska förutsättningar «. ${ }^{9}$

Det egalitära perspektivet återfinns även i statens syn på bredd- respektive elitidrott. I många länder avsätts betydande statliga summor för att främja den inhemska elitidrottens internationella konkurrenskraft. ${ }^{10}$ I Sverige har stödet däremot alltid haft en tydlig inriktning på breddidrott. De statliga argumenten för statsbidrag har nästan uteslutande kretsat kring folkhälsa, att främja demokratiska processer och social integration samt att erbjuda ungdomar ett aktivt och meningsfullt fritidsliv. ${ }^{11}$ Detta synsätt har även delats av idrottsrörelsen som i stor utsträckning utformat sin egen idrottsideologi utifrån ett brett förenings- och samhällsperspektiv med fokus på ideellt engagemang och allas rätt att delta utifrån sina egna förutsättningar och intressen. ${ }^{12}$ Denna betoning på bredd-idrott har visserligen inte förhindrat att statliga medel även kunnat utnyttjas till elitidrott (inte minst förbundens statliga organisationsstöd har alltid kunnat användas för landslagsverksamhet och deltagande $\mathrm{i}$ internationella idrottssammanhang). Poängen är istället att elitidrotten - med sitt starka fokus på elitism, rangordning och prestationer - varit alltför kontroversiell och spektakulär för att kunna inlemmas i en socialdemokratisk folkhemsdiskurs. Elitidrotten har således sällan accepterats 
som ett självständigt kulturfenomen. I den politiska retoriken har elitidrotten snarare accepterats än uppmuntrats - och detta utifrån devisen att »topp föder bredd«, det vill säga att elitens främsta förtjänst ligger i dens förmåga att locka nya barn och ungdomar till idrottsliga aktiviteter. $^{13}$

Det är först under senare år som statens syn på elitidrott börjat förändras. Ett viktigt genombrott kom 1998 genom ett regeringsbeslut att Sveriges olympiska kommitté (SOK) skulle få ett särskilt bidrag för talangutveckling. Detta följdes 2009 av en flerårig och förbundsövergripande elitsatsning på lite drygt 200 miljoner SEK. Parallellt beslutades att elitidrotten även skulle skrivas in i den förordning som reglerar statens stöd till idrotten. Utvecklingen under det senaste decenniet kan således sammanfattas som en breddning av statens idrottspolitiska ansvar till att även erkänna elitidrott som ett självständigt och bidragsberättigat kulturfenomen. ${ }^{14}$

\section{KORPORATISM OCH RIKSIDROTTSFÖRBUNDETS DUBBLA IDENTITET}

Ett tredje utmärkande drag för den svenska välfärdspolitiska modellen är intresseorganisationernas framträdande roll och inflytande. De klassiska folkrörelserna - nykterhetsrörelsen, väckelserörelsen och arbetarrörelsen - växte fram under 1800-talets andra hälft och kom att spela en viktig roll för demokratiseringen av det svenska samhället. Under 1900-talet fortsatte därefter organisationslivets expansion och konsolidering med följden att Sverige utvecklade en organiseringsgrad med få motsvarigheter hos jämförbara industriländer. Detta gäller än idag. Moderna studier visar att mer än 90 procent av den svenska befolkningen i åldern 16-84 år är medlem i åtminstone en frivillig organisation och att mer än var fjärde medborgare innehar ett oavlönat förtroendeuppdrag. ${ }^{15}$

I det svenska politiska systemet har intresseorganisationerna en stark och väletablerad ställning. De tillåts ofta delta i utredningar, utgör viktiga remissinstanser och utför olika former av myndighetsuppgifter. Till detta kommer att svensk politisk kultur ända sedan mellankrigstiden präglats av pragmatism och samförståndslösningar snarare än konflikt och revirstridigheter. $^{16}$

Alla dessa aspekter finns återspeglade i svensk idrottspolitik. Utan tvekan utgör den organiserade idrotten ett tydligt exempel på en klassisk, frivillig och föreningsdemokratiskt uppbyggd "folkrörelse«. Inom Riksidrottsförbundet samlas idag hela 3,3 miljoner medlemmar fördelade över drygt 20.000 lokala föreningar och 70 nationella idrottsförbund. ${ }^{17}$ Därtill har organisationen sedan länge utvecklat goda och nära kontakter med statens företrädare. I bidragsfrågor utvecklades redan under 1930-talet ett s.k. korporativt samarbete där den statliga administrationen begränsades till ett minimum och där alla praktiska frågor rörande statsanslagets fördelning och administration istället överläts till idrottsrörelsens egen ledning. Resultatet blev att Riksidrottsförbundet utvecklade en dubbel identitet. Organisationen är sedan länge högsta folkrörelseinstans och ställföreträdande myndighet på idrottsområdet. ${ }^{18}$

\section{EN MOTBILD: IDROTTEN SOM EN GÖKUNGE I DET SVENSKA VÄLFÄRDSBOET}

Redogörelsen ovan har visat att statens idrottspolitik i flera avseenden kan betraktas som en integrerad del av svensk välfärdspolitik - både ideologiskt och med hänvisning till politikens faktiska utformning. Men det går även att ge en motbild. I detta avsnitt skiftas följaktligen per- 
spektivet till de inslag i svensk idrottspolitik som inte följt det gängse mönstret. Redogörelsen tar sin utgångspunkt i ett brett historiskt perspektiv med tonvikt på idrottspolitikens utveckling under 1900-talets andra hälft. Syftet är tvåfaldigt. En första poäng är att idrottsfrågor generellt sett haft en både oklar och tillbakaträngd position i svensk politik. Den andra poängen är att detta varit synnerligen positivt för svensk idrott i ekonomiskt avseende.

\section{IDROTTENS OKLARA PLATS I DEN STATLIGA ADMINISTRATIONEN}

I den svenska statsförvaltningen är varje politisk sakfråga hänförd till ett av Regeringskansliets dryga tiotal departement. Placeringen är ofta tämligen given. Som exempel är det föga förvånande att lagstiftningsärenden hanteras av Justitiedepartementet medan turism och regional tillväxt sorterar under Näringsdepartementet. Ibland kan en frågas placering dessutom ge en fingervisning om hur statens företrädare uppfattar ämnet i fråga. Ett belysande exempel är spelpolitiken där en placering i Finansdepartementet antyder ett fokus på spelöverskottets betydelse för statens finanser medan en placering hos Socialdepartementet snarare skulle tyda på en oro för spelandets negativa skadeverkningar. $^{19}$

Mot denna bakgrund borde det varit relativt oproblematiskt att räkna ut vilka departement som ansvarat för idrottsfrågor i Sverige sedan statsanslagets tillkomst 1913. Men det är inte alls enkelt. Att försöka följa idrottsfrågornas vandring i svensk statsförvaltning skapar snarare förvirring än vägledning till hur statens företrädare uppfattat idrotten som politikområde. Det började visserligen begripligt. Vid statsanslagets tillkomst 1913 hänfördes idrottspolitiken till ecklesiastikministerns bord, det vill till hos ett departement med ett förhållandevis brett ansvarsområde innehållande allt från kyrkliga frågor till utbildning, ungdomsfostran och kultur. Under 1930-talet överfördes idrottspolitiken emellertid till Handelsdepartementet. 1971 övertog Jordbruksdepartementet ansvaret (med följden att idrottsanslaget tidvis redovisades under anslagsposten "miljövård m.m.«). I slutet av 1980-talet inleddes därefter en märklig period där ansvaret för idrottsfrågor i snabb takt slussades runt mellan Bostadsdepartementet, Finansdepartementet, Civildepartementet, Kulturdepartementet, Näringsdepartementet och Justitiedepartementet. Det finns säkert rationella eller åtminstone administrativa förklaringar till att idrottspolitiken flyttat runt inom Regeringskansliet. ${ }^{20}$ Men det är samtidigt även ett tydligt uttryck för att idrott utgjort ett både oklart och lite avvikande politikområde. Idrottspolitiken har sällan hänförts till - eller jämförts med - andra, närliggande politikområden. Därmed har ansvaret för idrottsfrågor även kunnat flyttas runt mellan departement av högst varierat slag. ${ }^{21}$

\section{DEN PARTIPOLITISKT "OVIKTIGA« IDROTTSPOLITIKEN}

En andra iakttagelse är att idrottsfrågor generellt sett uppfattats som "oviktiga« i en mer politisk mening. Under 1900-talet var idrotten inte ett område för partipolitisk profilering. I partiprogram och partimanifest förekom sällan hänvisningar till idrottsverksamhet. Därtill uppvisade riksdagens idrottsdebatter sällan partipolitiska skiljelinjer. Att i efterhand följa riksdagens många idrottsdebatter blir snart en påfallande enahanda läsning där företrädare från samtliga politiska partier uttrycker sitt stöd för idrotten och dess samhällsnytta. Den förändring i synen på idrottens samhällsnytta 
som trots allt framträder under 1900-talets gång (från nationalism och manlig ungdomsfostran vid seklets början till dagens betoning på folkhälsa och demokratiaspekter) blir därmed snarare en spegling av tidsandan och samhällsutvecklingen än ett uttryck för meningsskiljaktigheter mellan de politiska blocken.

Att idrottsfrågor saknade partipolitisk laddning fick två tydliga konsekvenser i riksdagen. För det första innebar det att idrotten utvecklades till en sorts politisk frizon - tillsammans med bland annat jakt och trosfrågor - där ledamöterna tilläts agera efter egen övertygelse och utan krav att följa en gemensam partilinje. ${ }^{22}$ För det andra skapades utrymme för idrottens företrädare att föra sin egen talan. Under 1950- och 1960-talet bildades följaktligen en liten blocköverskridande »lobbygrupp« bestående av riksdagsledamöter som även innehade ledande positioner inom svensk idrott. Mest aktiva var socialdemokraten Henry Allard (med tiden både talman och vice ordförande för Riksidrottsförbundet) och högermannen Birger Gezelius. Dessa två skrev återkommande gemensamma motioner om höjda idrottsanslag och lyckades vid flera tillfällen uppbringa ett imponerade stöd för idrottens sak bland övriga riksdagsledamöter. ${ }^{23}$

\section{DET STATLIGA IDROTTSSTÖDETS FINANSIERING}

Poängen med resonemanget ovan är att staten visserligen tidigt gav idrotten ett erkännande $i$ form av statligt stöd - men att idrottsfrågorna därefter utvecklades till ett närmast bagatellartat sidospår i svensk politik. Detta kan även uttydas i det statliga idrottsstödets finansiering.

I Sverige har huvudprincipen alltid varit att statsbidraget till idrotten - liksom alla andra offentliga utgifter - ska finansieras över statsbudgeten. Omfattningen på bidraget har således fastställts genom riksdagsbeslut inom ramen för årliga budgetprocesser efter prövning av idrottens behov i förhållande till andra offentliga utgifter och mot bakgrund av det statsfinansiella läget. I detta avseende skiljer sig svensk idrottspolitik från exempelvis Norge och Danmark där statsstödet sedan 1940-talet baserats på statliga intäkter från de nationellt reglerade spelmarknaderna. ${ }^{24}$

Att stater väljer att öronmärka överskottet från spelmarknaden till olika välgörande ändamål är vanligt förekommande. Samtidigt innebär det en finansieringsform som på väsentliga punkter avviker från traditionella statliga budgetprinciper. En första konsekvens är att det inte längre blir de politiska makthavarna - utan spelmarknadens utveckling - som i praktiken reglerar bidragets storlek. I det avseendet kan finansiering via spelmedel ses som en strategi där staten medvetet avsäger sig ett visst inflytande över ett politikområde. För det andra innebär det att ett visst mått av risk förs in i finansieringsfrågan. Det är nämligen alltid svårt att i förväg avgöra utvecklingen för en specifik spelform eller spelmarknaden i sin helhet. Politiska missbedömningar och oväntade händelser på spelmarknaden kan leda till kraftigt minskade anslag. Men samtidigt skapas det möjlighet till anslagsökningar som sällan kan åstadkommas inom ramen för den traditionella budgetprocessen.

Denna problematik är mycket tydligt i svensk idrottspolitik. Under tre begränsade perioder har nämligen även svensk idrott tilldelats spelmedel. Vid samtliga tillfällen har följderna blivit både oväntade och långtgående med avseende på statsbidragets omfattning. ${ }^{25}$

\section{8 ÅRS IDROTTSLOTTERI}

Det första exemplet handlar om ett idrottslotteri som regeringen lät bevilja 1908. Lotteriets 
tillkomst var en direkt följd av att riksdagen under flera år avslagit regeringens förslag om statsbidrag till idrottsrörelsen. Att tillföra idrotten spelmedel var således en strategi från regeringens sida för att aktivt stödja den spirande idrottsrörelsen trots riksdagens motstånd. Lot-

teriet blev emellertid inte enbart ett alternativ till traditionellt statsbidrag. Med idrottslotteriet skapades nämligen de ekonomiska förutsättningarna för Stockholm att arrangera 1912 års Olympiska spel, inklusive anläggandet av det monumentala byggnadsverket Olympiastadion. Och de stora svenska framgångarna vid "solskens-olympiaden « fick därefter avgörande betydelse för att riksdagen sedermera övergav sin tidigare så negativa attityd till idrottsverksamhet. Med början 1913 fick idrottsrörelsen följaktligen sitt anslag. Därmed spelade spelmarknaden åtminstone indirekt en viktig roll för att idrottsrörelsen kom i åtnjutande av ett permanent och årligt offentligt stöd.

TOTOholdet med damer ankommer til Kastrup lufthavn

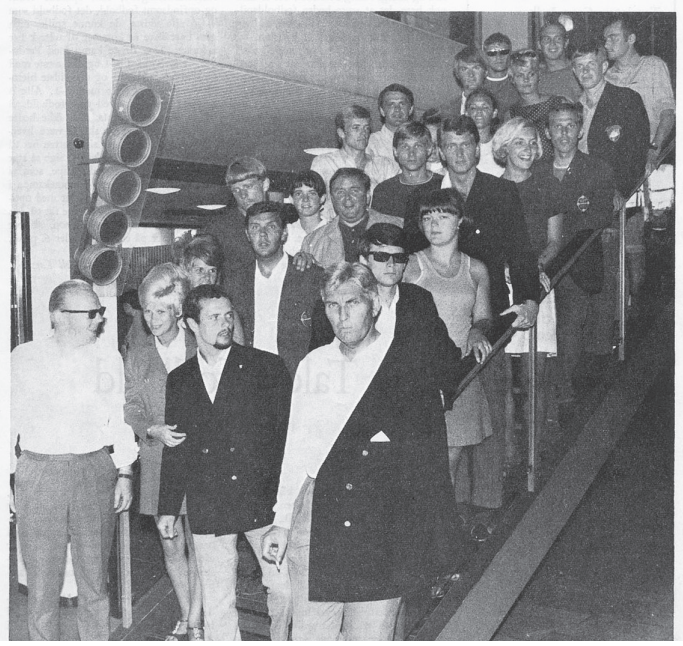

Danmark var kraftigt inspireret af Sverige i arbejdet for at få tipning tilladt. Det var Danmarks Olympiske Komité, der gik forrest. De søgte i 1936 staten om lov til at tilbyde tipning. DIF var dog modstander af det, da de var bange for, at spillet ville forurene idrætten og dermed overskygge udøvernes lyst til idræet. I 1946 kom DIF dog på andre tanker, og vejen var banet for tips på dansk grund. I 1949 lancerede Dansk Tipstjeneste den første tipskupon. Med tiden blev den europæiske fodboldturnering, тото-Cuppen, en stor tipssucces. Her ses et hold fra Boldklubben Frem, der i 1969 deltog i TOTO-cuppen. (Foto udlånt af Boldklubben Frem)

\section{MELLANKRIGSTIDENS "TIPSFRÅGA"}

Det andra tillfället inföll i mitten av 1930-talet. Bakgrunden var denna gång att regeringen ville stävja de många illegala tipsspel som florerade i landet. Genom att legalisera tips - och samtidigt ge ett statligt kontrollerat spelbolag, AB Tipstjänst, ensamrätt till denna spelform - avsåg regeringen således att både konkurrera ut de många illegala spelbolagen och samtidigt erbjuda allmänheten tipsspel under säkra och kontrollerade former. Men hur skulle det framtida spelöverskottet hanteras? Efter visst övervägande beslutade regeringen att öronmärka hela Tipstjänsts överskott till idrottsändamål. Detta var logiskt såtillvida att tipsspel baserades på resultat i idrottstävlingar. Därtill var ju alla andra tillåtna spelformer i Sverige (lotterier, totalisatorspel) också förbehållna olika samhällsnyttiga mål. Slutligen gjordes bedömningen att det stora intresset för tips inte skulle bestå särskilt länge. Därmed uppfattades det inte heller som särskilt problematiskt att ge idrottsrörelsen ett välbehövligt - men säkerligen tillfälligt - ekonomiskt tillskott. 
Det sista visade sig emellertid vara en grov underskattning av det svenska folkets stora intresse för spel och dobbel. Tipstjänst blev omgående ett mycket vinstgenererande företag - och detta ledde i sin tur till en närmast explosionsartad ökning av statens idrottsstöd. Här talar siffrorna sitt tydliga språk. Under åren 19131934 hade idrottens totala statsanslag uppgått till drygt två miljoner kronor. Under de nästföljande fem åren tillfördes idrottsrörelsen hela 23 miljoner kronor.

De stora framgångarna för Tipstjänst fick regeringens företrädare att ångra sitt tipslöfte till idrottsrörelsen. Utbrottet av andra världskriget 1939 framtvingade dessutom kraftiga besparingar över hela statsbudgeten. För idrottens del medförde således beredskapspolitiken att hela Tipstjänsts överskott istället tillfördes statskassan och att idrottsanslaget återigen utdelades över statsbudgeten, dvs i form av skattemedel. Denna ordning kom därefter att bestå i decennier. De faktiska beloppen blev emellertid betydligt högre än de bidragssummor som utdelats före Tipstjänsts tillkomst. Därmed kan 1930-talets tipsfråga betraktas som utlösande faktor till idrottens definitiva genombrott i det svenska välfärdsbygget.

I Norge och Danmark bevakades den svenska utvecklingen i tipsfrågan med stort intresse. Kort efter andra världskrigets slut inrättade dessutom båda länder egna motsvarigheter med statligt kontrollerade tipsbolag vars överskott knöts till idrottsliga ändamål. ${ }^{26}$ Denna ordning gäller än idag. Även om tipsfrågan således blev en kort epok för svenskt vidkommande, bidrog den således till att förändra den statliga idrottspolitikens utformning och finansiering i både Danmark och Norge.

\section{NYA SPELBIDRAG TILL IDROTTEN SEDAN}

\section{0-TALET}

Under 1940-talet återinfördes således principen att statens idrottsstöd skulle baseras på skatteintäkter - och att överskottet från den reglerade spelmarknaden skulle tillföras statskassan (med undantag för s.k. totalisatorspel som av tradition i Sverige alltid varit öronmärkt för svensk hästnäring och hästsport).

Först under 1990-talet togs förnyade initiativ till att koppla statens idrottsstöd till spelmarknaden. Bakgrunden ska denna gång sökas i den svåra ekonomiska kris som Sverige upplevde i början av decenniet. För idrottens del hade det problematiska statsfinansiella läget utmynnat $\mathrm{i}$ både höjda omkostnader och minskade bidrag. Och trots återkommande propåer var ökat stöd över statsbudgeten inte att vänta. Mot denna bakgrund riktades blickarna mot spelmarknaden. Idrottsrörelsen hade alldeles nyligen beviljats ett mindre anslag via Tipstjänst som kompensation för att spelbolaget anordnade spel på idrottsevenemang. Kanske kunde staten förmås öka detta stöd? Våren 1994 kom riksdagens svar. Lösningen blev att låta inrätta en ny spelform i Sverige (s.k. värdeautomater, i praktiken en modern form av "enarmade banditer «) och att reservera hela överskott från denna spelform till det svenska föreningslivets barn- och ungdomsverksamhet på lokal nivå, varav merparten till idrottsrörelsen.

Även denna gång blev resultatet en högvinst. De nya värdeautomaterna blev snabbt populära och 1999 kunde därmed ett första spelbidrag på 110 miljoner SEK delas ut, utöver ett traditionellt statsanslag på cirka 470 miljoner SEK. Därefter fortsatte spelmedlen att öka i snabb takt. Efter tre år passerades 400 miljonersstrecket. Året därpå blev resultatet drygt 660 miljoner SEK. Därmed var idrottens intäkter 
från spelmarknaden vida överstigande statsbidraget över statsbudgeten. Precis som 1930-talets tipsspel så spred nu återigen spelmarknaden ett närmast okontrollerat guldregn över svensk idrott.

Denna gång såg emellertid regeringen ingen anledning att begränsa idrottens intäkter från spelmarknaden. Tvärtom. I slutskedet av 2002 års valrörelse meddelade socialdemokraterna att man avsåg att satsa ytterligare en miljard SEK av statens intäkter från spelmarknaden på en storskalig satsning på lokala utvecklingsprojekt inom idrotten, det s.k. " handslaget «. Denna satsning förstärktes därefter till två miljarder SEK per mandatperiod i det "idrottlyft" som den borgerliga alliansregeringen införde 2007.
Det totala statliga idrottsanslagets utveckling under perioden 1999-2009 redovisas nedan.

Tabell 1 visar att statens samlade stöd till idrotten ökade med cirka 300 procent under perioden 1999-2009. Utvecklingen har flera likheter med 1930-talets tipsfråga. För det första skapade kopplingen till spelmarknaden en exceptionell höjning av statens stöd till idrotten som rimligtvis aldrig hade varit möjligt att åstadkomma om idrottsanslaget hade förblivit finansierat över statsbudgeten. För det andra var det en koppling som endast bestod under en kort period. Med början 2010 har nämligen regeringen beslutat att successivt avskaffa principen med idrottsstöd via spelmarknadens överskott. Beslutet att återigen finansiera idrottsrörelsen

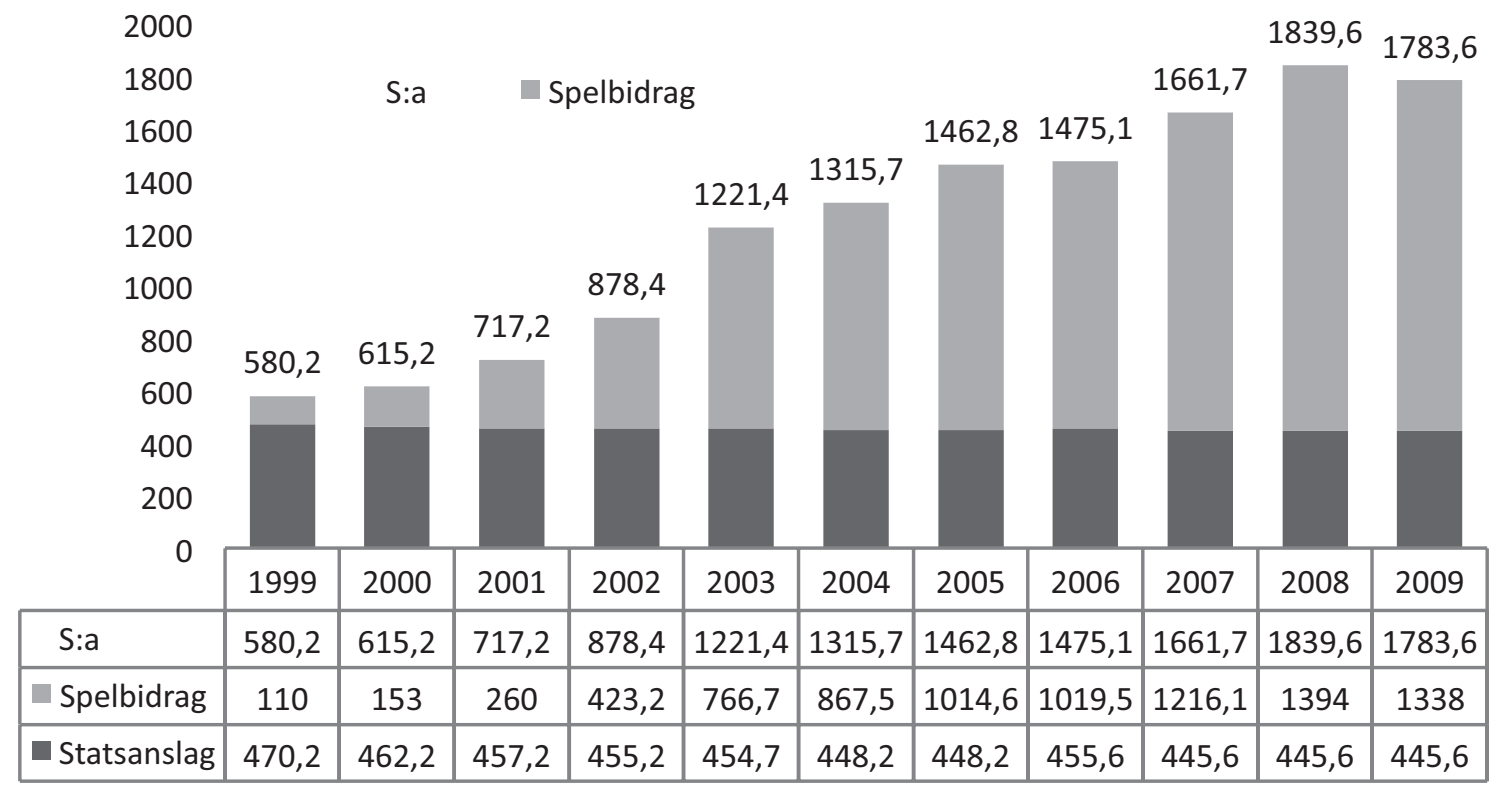

Tabel 1. Statens stöd till idrotten 1999-2009, SEK 
över statsbudgeten har framförallt motiverats som en strategi för att undvika framtida anslagsminskningar om/när statens överskott från spelmarknaden kommer att minska till följd av ökad internationell konkurrens på spelområdet. Omfattningen på det statliga stödet har emellertid förblivit kring 1,8 miljarder SEK. Precis som under 1930-talet har ett scenario således utspelats där spelmarknaden först bidragit till att kraftigt höja statens idrottsstöd - och att anslaget därefter återigen inordnats i statsbudgeten, fast på nya, högre nivåer.

\section{MOT EN NY IDROTTSPOLITIK?}

Historiker har till profession att analysera det förflutna - inte att sia om framtiden. Med denna reservation finns det emellertid skäl att lyfta fram ett antal aktuella förändringsprocesser i svensk idrottspolitik. Det finns nämligen tydliga indikationer på att idrottspolitiken håller på att förlora sin tidigare särställning som ett udda sidospår i den statliga välfärdspolitiken.

En första förändring rör själva ansvarsfördelningen mellan staten och idrottsrörelsen. Sedan 1990-talets senare hälft har regeringen vidtagit flera åtgärder i syfte att förtydliga statens idrottspolitiska förväntningar och mål. Syftena med statens idrottsstöd har preciserats i en särskild förordning. Delar av Riksidrottsförbundets myndighetsutövning har reglerats i förvaltningslagen. Därtill har uppföljningen av statens stöd systematiserats genom ett särskilt uppdrag till Centrum för idrottsforskning. ${ }^{27}$ I finansieringsfrågor har - som visats ovan - kopplingen till AB Svenska Spel successivt avskaffats med följden att statens idrottsstöd sedan 2011 uteslutande finansieras över statsbudgeten.

En andra förändring rör idrottspolitikens placering i den offentliga förvaltningen. Även här har förutsägbarheten ökat. Ett första steg togs
2001 genom att idrottsfrågor integrerades i det nyinrättade politikområdet »Folkrörelsepolitik«. År 2006 överfördes folkrörelsepolitiken dessutom från Justitiedepartementet till Kulturdepartementet. Samtidigt etablerades principen att kulturministern med automatik även ansvarar för folkrörelse- och idrottsfrågor. ${ }^{28}$

Sedan millennieskiftet går det även att skönja mer övergripande förändringar i idrottens samhällsroll och samhällslegitimitet. En viktig sådan är att idrotten börjat framstå som ett allt viktigare politikområde. Nästan alla riksdagspartier vill numera profilera sig som idrottsrörelsen stora välgörare. Ett avgörande steg togs i 2002 års valrörelse genom socialdemokraternas utspel om den s.k. "handslags«-miljarden. ${ }^{29}$ Därefter har det blivit i det närmaste kutym för båda politiska block att presentera storstilade satsningar på idrotten $\mathrm{i}$ både valmanifest och regeringsförklaringar. I 2010 års val lanserade socialdemokraterna dessutom den populäre höjdhopparen Staffan Holm som tänkbar idrottsminister i en framtida socialdemokratisk ministär. Utspelet fick stort medialt genomslag och förstärker intrycket att idrotten numera uppfattas som en fråga av betydelse för medborgarnas beslut på valdagen.

Den skisserade utvecklingen kan således sammanfattas i två parallella processer. Den första är att idrottspolitiken alltmer förlorar sin tidigare karaktär som svårdefinierat sidospår i svensk politik. Den andra är att idrotten utvecklats till ett område för partipolitisk profilering. Effekten av detta är att idrotten utvecklats till ett viktigare politikområde - men också mer traditionellt och förutsägbart.

För idrottsrörelsen är denna utveckling på gott och ont. En positiv aspekt är att idrotten blivit en allt viktigare fråga i den politiska samhällsdebatten. Detta borgar för fortsatt offent- 
ligt stöd och goda relationer med den politiska makten, oavsett partifärg. Mot detta står att idrottsrörelsen inte längre kan utnyttja de fördelar som trots allt låg i idrottens position som ett udda och »oviktigt» sidospår i den statliga politiken. Som exempel är det inte längre möjligt för idrotten att erhålla anslagsökningar i den omfattning som möjliggjordes av spelpengarna under åren 1999-2009. Därtill har rörelsens oberoende begränsats i takt med att staten preciserat nya och tydliga mål för sin bidragsgivning och därtill infört rutiner för att följa upp det offentliga stödets utnyttjande.

\section{SLUTORD}

Syftet med denna artikel har varit att ge en karakteristik av statens idrottspolitik i Sverige. Analysen har gjorts efter två huvudlinjer. Först har jag visat att idrottspolitiken i vissa avseenden alltid utgjort en integrerad del av svensk välfärdspolitik. Därefter har jag även lyft fram viktiga olikheter med innebörden att idrotten på goda grunder kan beskrivas som en "gökunge i välfärdsboet «, det vill säga som ett lite udda politikområde men med anmärkningsvärd förmåga att tillskansa sig allt större bitar av den offentliga välfärdskakan. Avslutningsvis har jag argumenterat för att idrottspolitiken under senare år förlorat mycket av sin tidigare position som ett svårplacerat och »oviktigt « sidospår i statens välfärdspolitik. Förändringen kan sammanfattas som att idrotten stärkt sin position i svensk välfärdspolitik - men att idrott som politikområde samtidigt blivit mer traditionellt, förutsägbart och...ja, även lite tråkigare.

\section{REFERENSER}

Bergsgard, N.A. (2002). "Spillet om spillemidlene«. I: P. Mangset \& H. Rommetvedt (red.) Idrett og politikk. Kampsport eller lagspill? Bergen: Fagbokforlaget.

Bergsgard, N. A., Houlihan, B., Mangset, P., Nødland, S. I. \& Rommetvedt, H. (2007). Sport Policy - A Comparative Analysis of Stability and Change. Oxford: Butterworth-Heinemann.

Bergsgard, N. A. \& Norberg, J. R. (2010). „Sports policy and politics - the Scandinavian way«. Sport in Society Cultures, Commerce, Media, Politics, 13(4).

Bøje, C. \& Eichberg, H. (1994). Idrattens tredje vej-om idratten i kulturpolitikken. Århus: Klim.

De Bosscher, V., Bingham, J., Shibli, S., Van Bottenburg, M. \& De Knop, P. (2008). The global Sporting Arms Race. An international comparative study on sports policy factors leading to international sporting success. Aachen: Meyer \& Meyer.

Esping-Andersen, G. (1990). Three Worlds of Welfare Capitalism. Oxford: Polity.

Föreningslivet i Sverige (2003). Stockholm: Statistiska centralbyrån.

Goksøyr, M., Andersen, E. \& Asdal, K. (1996). Kropp, kultur og tippekamp. Statens idrettskontor, STUI og Idrettsavdelningen 1946-1996. Oslo: Universitetsforlaget. 
Ibsen, B. (2002). "En eller flere idrætsorganisationer - hvorfor forskelle mellem de nordiske lande«. I: H. Eichberg \& B. V. Madsen, (red.) Idrattens enhed eller mangfoldighed, Bevægelsestudier 1. Århus: Klim.

Ibsen, B. \& Ottesen, L. (2004). "Sport and Welfare Policies in Denmark«. I: K. Heinemann, (red.) Sport and Welfare Policies. Six European Case Studies. Series Club of Cologne, Vol. 3.

Ibsen, B. \& Eichberg, H. (2006). Dansk idrcetspolitik. Mellem frivillighed og statslig styring. København: Idan.

Idrotten vill - idrottsrörelsens idéprogram, antaget av RF-stämman 2009. Stockholm: Riksidrottsförbundet.

Larsson, T. \& Bäck, H. (2008). Governing and governance in Sweden. Lund: Studentlitteratur.

Lindroth, J. (1994). Idrottens fyra samhällsroller: ett diskussionsunderlag. Stockholm: Institutet för fritidsvetenskapliga studier.

Lundström, T. \& Wijkström, F. (1995). Från röst till service? Den svenska ideella sektorn $i$ förändring. Sköndal: Sköndalsinstitutet.

Micheletti, M. (19949). Det civila samhället och staten. Medborgarsammanslutningarnas roll $i$ svensk politik, Stockholm: Fritze.

Norberg, J. R. (1998). "A Mutual Dependency. The Nordic Sport and the State«. I: H. Meinander, \& J. A. Mangan, (red.) The Nordic World. Sport in Society. London: Cass.
Norberg, J. R (20029). »Idrotten och staten«. I J Lindroth \& J. R. Norberg, (red.) Ett idrottssekel. Riksidrottsförbundet 1903-2003. Stockholm: Informationsförlaget.

Norberg, J. R. (2004). Idrottens väg till folkhemmet. Studier $i$ statlig idrottspolitik 1913-1970. Stockholm: SISU Idrottsböcker.

Norberg, J. R. (2010). »Idrottens spelberoende. Tre tillfällen då spelmarknaden förändrat svensk idrottspolitik«. Idrott, historia och samhälle. SVIF.

Norberg, J. R. \& Dartsch, C. (2010). „CIF's nya uppdrag att ansvara för en regelbunden och långsiktig uppföljning av statens stöd till idrotten«. Svensk idrottsforskning, 1.

Norberg, J. R. \& Sjöblom, P. (under utgivning). "The Swedish elite sport system - or the lack of it? « I: S. Andersen \& L. T. Ronglan (red.) Nordic elite sport - is organization and leadership the key? Oslo: Norwegian University .

Regeringens proposition 2008/09:126. Statens stöd till idrotten.

Riksidrottsförbundets stadgar i lydelse efter RF-stämman 2009.

Rothstein, B. (1992). Den korporativa staten. Intresseorganisationer och statsförvaltning $i$ svensk politik. Stockholm: Norstedts juridik.

Rothstein, Bo (1994). Vad bör staten göra? Om välfärdsstatens moraliska och politiska logik. Stockholm: SNS. 
SOU 2008:59. Föreningsfostran och tävlingsfostran. En utvärdering av statens stöd till idrotten. Betänkande av Idrottsstödsutredningen.

Tillsammans för trygghet och utveckling - Socialdemokraternas valmanifest 2002-2006.

Uppföljning av statens stöd till idrotten (2011). Stockholm: Centrum för idrottsforskning.

\section{NOTER}

1. För en diskussion om idrottspolitiken i Norge, Sverige och Danmark i relation till skandinavisk välfärdspolitik, se Bergsgard \& Norberg (2010) och Norberg (1998).

2. Larsson \& Bäck (2008), s. 257.

3. Esping-Andersen (1990).

4. För en historisk redogörelse av statens idrottspolitik i Sverige, se Norberg (2004).

5. Jfr. Bergsgard et al. (2007), s. 6-8. Se även Bergsgard \& Norberg (2010), s. 574.

6. Uppföljning av statens stöd till idrotten (2011), s. 13-16.

7. SOU $2008: 59$, s. $184-185$.

8. Rothstein (1994) och Ibsen \& Ottesen (2004).

9. Riksidrottsförbundets stadgar i lydelse efter RF-stämman 2009, kap. 1.
10. Se exempelvis De Bosscher et al. (2008).

11. Jfr. SOU 2008:59, kap. 4.

12. Idrotten vill - idrottsrörelsens idéprogram, antaget av RFstämman (2009).

13. Jfr. Bøje \& Eichberg (1994).

14. Norberg \& Sjöblom (under utgivning).

15. Lundström \& Wijkström (1995) Se även Föreningslivet $i$ Sverige (2003), s. 24-33.

16. Rothstein (1992).

17. För statistik om svensk idrott, se Uppföljning av statens stöd till idrotten, kap. 3.

18. Lindroth (1994).

19. För en redogörelse av den svenska idrottens finansiering via spel, se Norberg (2010).

20. En bidragande orsak kan vara att ansvaret för idrottsfrågor i regeringen ofta hänförts till det statsråd som varit mest idrottsintresserad. Även detta förstärker f.ö. bilden av idrottspolitiken som ett annorlunda politikområde.

21. Jfr. Norberg (2002), s. 222.

22. Norberg (2004), s. 442-443.

23. Norberg (2004), kap. 5.

24. Jfr. Bergsgard (2002) och Ibsen \& Eichberg (2006).

25. Denna redogörelse är hämtad från Norberg (2010).

26. Goksøyr et al. (1996), Ibsen \& Eichberg (2006) och Norberg (1998).

27. Regeringens proposition 2008/09, s. 126. Se även Norberg \& Dartsch (2010).

28. SOU 2008:59, s. 136-137.

29. Tillsammans för trygghet och utveckling - Socialdemokraternas valmanifest 2002-2006. 